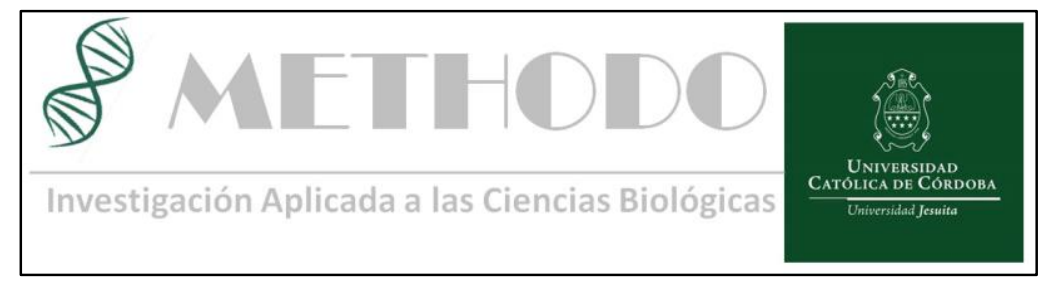

\title{
Diagnóstico de enfermedad granulomatosa crónica (EGC): perspectiva desde la resolución de un caso clínico
}

\section{Diagnosis of chronic granulomatous disease (CGD): perspective from the resolution of a clinical case}

\author{
Graciela Alegre ${ }^{1}$, Alejandro Lozano ${ }^{1}$, Vanina Marini ${ }^{1}$, Natalia A. Lozano ${ }^{1}$, Ricardo J. Saranz ${ }^{1}$, Ana G \\ Sosa Aguirre ${ }^{1}$, Silvia Danelian ${ }^{2}$, Matías Oleastro ${ }^{3}$. \\ 1 Servicio de alergia e inmunología. Clínica Universitaria Reina Fabiola, Universidad Católica de Córdoba \\ 2 Servicio Biología Molecular, Hospital Prof. Dr. Juan Pedro Garrahan. Ciudad Autónoma de Buenos Aires \\ 3 Servicio de inmunología, Hospital Prof. Dr. Juan Pedro Garrahan. Ciudad Autónoma de Buenos Aires. Correspondencia: Graciela. Alegre. Servicio de Alergia e \\ Inmunología. Clínica Universitaria Reina Fabiola Oncativo 1248-X5004FHP-Cordoba, Argentina; email: graalegre98@ gmail.com
}

\section{Introducción}

La EGC es una patología de baja prevalencia incluida en el grupo de los defectos congénitos de los fagocitos ${ }^{1}$. Existen dos formas de transmisión genética: ligada a $\mathrm{X}$, la más frecuente y grave, y autosómica recesiva ${ }^{2}$. Se debe a mutaciones de los genes que codifican para las proteínas que constituyen el complejo NADP oxidasa lo que induce incapacidad en fagocitos para realizar el estallido respiratorio ${ }^{3,4}$. El diagnóstico se fundamenta en el fenotipo clínico y de laboratorio; la prueba de dihidrorodamina (DHR) con estímulo de PMA por citometría de flujo es el método diagnóstico de elección ${ }^{5}$. El diagnóstico definitivo es la identificación de la mutación genética por secuenciación del $\mathrm{ADN}^{2}$. La terapéutica curativa de esta patología es el trasplante de células madres hematopoyéticas (TCHP) ${ }^{6}$.

\section{Informe del caso}

Niño de 4 años que desde los primeros meses de vida padeció abscesos en piel y región perianal recurrentes por Staphilococcus aureus. Como antecedentes de la enfermedad presentó lesión ganglionar persistente y supurativa por BCG. La evolución clínica fue tórpida con mala respuesta a la antibioticoterapia. En el laboratorio se demostraron todos los valores normales, excepto la DHR que evidenció una alteración en la capacidad oxidativa de los fagocitos, diagnóstico probable de EGC. Se realizó DHR en la madre y la tía materna donde se evidenció la condición de portadora de la madre, y sana de la tía. Se documentó una mutación deletérea p. Trp443X en el exón 11 del gen CYBB en estado hemicigota en el niño y en estado heterocigota en la madre.

El niño, aún con la profilaxis antimicrobiana instalada, continuó con abscesos y necesitó tratamiento antimicobacteria para su persistente BCGitis. Por otro lado, desarrolló enfermedad inflamatoria intestinal grave que implicó el uso de agente biológico antiTNF (infliximab).

A la edad de 3 años y 8 meses se realizó TCHP con donante no emparentado compatible $10 / 10$ para antígenos del complejo principal de histocompatibilidad tras recibir como preparación busulfan y ciclosporina.

A los 6 meses del procedimiento presentó un $95 \%$ de células obtenidas de sangre de origen del donante. La prueba de DHR evidenció la reconstitución de la capacidad oxidativa de los neutrófilos. En la evolución clínica pos-trasplante, 
el niño superó todas sus infecciones y se comporta como un sujeto inmunocompetente.

\section{Conclusión}

El niño padeció de EGC, una enfermedad grave e infrecuente.

La prueba de DHR permite el diagnóstico probable de EGC y del estado de portación, así como la condición de actividad normal. El estudio genético es confirmatorio.

\begin{abstract}
CGD is a low prevalence pathology included in the group of congenital phagocyte defects ${ }^{1}$. There are two forms of genetic transmission: the X-linked, the most frequent and severe, and autosomal recessive ${ }^{2}$. It is due to a mutation of the genes coding for proteins that constitute the NADP oxidase complex, which induces inability of phagocytes to perform respiratory burst ${ }^{3,4}$. The initial diagnosis is based on the clinical and laboratory phenotype; the dihydrorhodamine (DHR) test with PMA stimulation by flow cytometry is a diagnostic method of choice ${ }^{5}$. The demonstration of the genetic mutation by DNA sequencing is the definitive diagnosis ${ }^{2}$. The haemopoietic stem-cell transplantation (HSCT) is the curative therapy of this pathology ${ }^{6}$.
\end{abstract}

\section{Case Report}

A 4-year-old child, from the first months of life, had recurrent abscesses in the skin and perianal region from Staphylococcus aureus. The patient had a persistent and suppurative ganglionic lesion due to BCG. The clinical evolution was torpid with poor response to antibiotic therapy. All normal values were demonstrated in the laboratory, except DHR, which showed an alteration in the oxidative capacity of phagocytes, a probable diagnosis of EGC. DHR was performed on the mother and maternal aunt where the condition of the mother's carrier was evidenced, and the aunt's health. A deleterious p. Trp443X mutation was documented in exon 11 of the CYBB gene in the hemicite state in the child and in the heterozygote status in the mother.

The child, even with antimicrobial prophylaxis installed, continued with abscesses and required antimycobacterial treatment for their persistent bcgitis. On the other hand, developed severe inflammatory bowel disease that involved the use of anti-TNF agent (infliximab).

At the age of 3 years and 8 months HSCT was performed with $10 / 10$ compatible non-related donor for major histocompatibility complex antigens after receiving as preparation busulfan and cyclosporine.

At 6 months of the procedure, $95 \%$ of cells obtained from blood of the donor origin were present. The DHR test showed the reconstitution of oxidative capacity of neutrophils. In posttransplantation clinical evolution, the child overcame all his infections and behaves as an immunocompetent subject.

\section{Conclusion}

The child had CGD, a serious and infrequent illness.

The DHR test allows the probable diagnosis of CGD and porting status as well as the normal activity condition. The genetic study is confirmatory.

Allogeneic bone marrow transplantation is the curative option for this pathology.

\section{Bibliografía}

1. Picard C, Al-Herz W, Bousfiha A, Casanova $\mathrm{JL}$, et al Primary Immunodeficiency Diseases: an Update on the Classification from the International Unionof Immunological Societies Expert Committeefor Primary Immunodeficiency 2015 J Clin Immunol 2015;35:696-726

2. Borges de Oliveira-Junior E, Bengala Zurro $\mathrm{N}$, Prando C, Cabral-Marques O, et al. Clinical and Genotypic Spectrum of Chronic Granulomatous Disease in 71 Latin American Patients: First Report From the LASID Registry. Pediatr Blood Cancer 2015; 62:2101-2107

3. Roos D, Kuhns DB, Maddalena A, Roesler J, Lopez JA, Ariga T, Avcin T, de Boer M, Bustamante J, Condino-Neto A, Di Matteo G, He J, Hill HR, Holland SM, Kannengiesser C, K€oker MY, Kondratenko I, van Leeuwen K, Malech HL, Marodi L. Hematologically important mutations: X-linked chronic granulomatous disease (third update). Blood Cells Mol Dis 2010; 45:246-265

4. Roos D, Kuhns DB, Maddalena A, Bustamante J, Kannengiesser C, de Boer M, van Leeuwen $\mathrm{K}$, K€oker MY, Wolach B, Roesler J, Malech HL, Holland SM, Gallin JI, Stasia MJ. Hematologically important mutations: The autosomal recessive forms of chronic granulomatous disease (second update). Blood Cells Mol Dis 2010; 44:291299. 
5. El Hawary R,Meshaal S, Deswarte C, Galal $\mathrm{N}$, et al. Role of Flow Cytometry in the Diagnosis of Chronic Granulomatous Disease: the Egyptian Experience J Clin Immunol 2016; 36:610-618

6. Ramírez-Uribe N1, Hernández-Martínez C, López-Hernández G, Pérez-García M, et al. Hematopoietic progenitors transplantation in a patient with chronic granulomatous disease in Mexico Rev Alerg Mex2016;63(1):95-103.

\section{Palabras claves}

INMUNODEFICIENCIA PRIMARIA, ENFERMEDADGRANULOMATOSA CRÓNICA, TEST DE DIHIDRORODAMINA, TRASPLANTE DE CÉLULAS MADRE HEMATOPOYÉTIC.

\section{Keywords}

PRIMARY IMMUNODEFICIENCY CHRONIC GRANULOMATOUS DISEASE, DIHYDRORHODAMINE TEST, HAEMATOPOIETICSTEMCELL TRANSPLANTATION

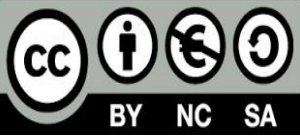

